\title{
H. L. Golterman, freshwater ecologist, 1928-2018
}

\author{
J. G. M. Schouffoer
}

Received: 2 December 2018/Revised: 3 February 2019/Accepted: 9 February 2019/Published online: 4 March 2019

(C) Springer Nature Switzerland AG 2019

Doctor Golterman-Han for all who had the privilege to work with him — was a remarkable scientist and also a loyal colleague and friend.

During his studies at Amsterdam University, Han Golterman switched from physical chemistry to biochemistry. He came in contact with Professor A.W.H. Van Herk, whom he admired for his logical approach to plant physiology and became his assistant. Already in this period, Han Golterman made a start with studying Phosphate cycles in the Amsterdam Hortus. Shortly after his graduation, under the guidance of Van Herk, he started his research on the cycling of elements in freshwater lakes and obtained his Ph.D. in 1960. At the same time, Han Golterman was involved in the start of the Nieuwersluis Hydrobiological Institute and was appointed as scientific director where he worked together with the first head of the institute Dr. (Mrs) M. F. (Emily) Nicolai. Together they worked on the development of the new founded institute that later became the Limnological

\footnotetext{
Author worked with Han Golterman in the Association 'Leiden-Camargue' and presently works as independent water government advisor in The Netherlands. He wishes to thank Dr. Laura Serrano and Dr. Marlous Blankesteijn for their comments.
}

J. G. M. Schouffoer $(\square)$

Agence des Eaux, Leiden, The Netherlands

e-mail: hschouffoer@kpnmail.nl
Institute and is, at present, part of the Netherlands Institute of Ecology (NIOO-KNAW).

At a young age, unexpected and unsolicited, he also was given the overall management responsibility for the institute, next to his scientific responsibility. Between 1961 and 1978, he developed the Limnological Institute to become an authoritative research institute and carried out pioneering research-in particular by Dutch standards-concerning, amongst other places, lake Vechten and lake Tjeukemeer. Golterman played a crucial role in turning focus of Dutch limnology on merely (mode 1) production of academic knowledge towards a more (mode 2) interdisciplinary approach on knowledge production to work on environmental problems.

Under his leadership, the institute grew and earned international recognition. The participation of the institute in the UNESCO IBP program greatly promoted limnology in The Netherlands. Golterman pioneered international concern on sediment chemistry in limnological studies during the first symposium on the "Interaction between Water and Sediment" held in Amsterdam in 1976 (Golterman, 1977a, b). Since then, he became a widely recognised expert, and acted as editor of the water-sediment issues of the journal Hydrobiologia for many years.

The IBP brought Han Golterman close to some of the best-known limnology institutes abroad, particularly in the United Kingdom: Windermere laboratory in Cumbria and the University of Liverpool. These 
contacts attracted several graduate students to Nieuwersluis and the fieldlab at lake Tjeukemeer. Dozens of young researchers gained practical experience collecting data on the lake and studying them in the field lab. Han Golterman was strongly influenced by the famous Baas Becking who wrote "Field ecology can never give us a complete description of the environment; this privilege belongs to the laboratory" (Baas Becking, 1934). In this period, as director of the Institute, he not only laid the foundations of research in physical-chemical limnology in the Netherlands, especially phosphorus dynamics and water sediment interactions, but also expanded the scope of limnological research on Dutch lakes (Gulati, 1995).

Notwithstanding the successful development, the road was rough and not without difficulties. The work at Nieuwersluis was a very demanding job for the scientist and manager Golterman. Ramesh Gulati, one of his first co-workers, described this challenging period in a special issue of Hydrobiologia. During the turbulent sixties, Golterman kept his footing. Those years during which the authorities were up for discussion, also were the years of the Club of Rome, and the years when thick stinking layers of foam could be found on the Dutch canals and rivers. As the manager of the Limnological Institute, he played a very active part in the swelling public discussion about the impact of the increasing industrialization on the water quality in the Netherlands: the emission from the industries and agriculture caused a huge decline in water quality and major social and ecological problems.

Han Golterman was the first one in the Netherlands who addressed eutrophication as a huge and complex problem for the freshwater system. With his research and debates, he made a valuable contribution to the Dutch legislation on water quality. Partly due to his call to tackle the phosphate problem, the so-called Phosfate Urgency Memorandum was produced in 1972. In this note, the national government mentioned the first steps to 'dephosphating' and the tackling of detergents as the solution. From the viewpoint of Golterman and the other members of the Steering Committee of the Royal Netherlands Chemical Society (KNCV) that was definitely not enough. Under the leadership of Golterman and with the cooperation of a wide group of researchers, the KNCV Steering Committee had examined the causes and increase in eutrophication after the Second World War and this was published in the report 'Phosphates in the Dutch Surface Waters' (Golterman, 1976). Draining of untreated sewage from households, the use of phosphate rich detergents, and the bio-industry were indicated as the major causes. The policy theory to avoid P-emissions found response in the work of the government Committee on the Implementation of the surface water pollution law (CUVCO), and in the objectives of the (feminist) action group 'Anti whiter than white' (Blankesteijn, 2011).

The Dutch waterboards, NGOs, and industries managed to limit the phosphate emissions from industries and households, but from the national Ministry of Agriculture there was still denial about the influence of agriculture for decades, and in the year 2018 the last word on the solution of the eutrophication problem unfortunately has still not been spoken in The Netherlands (Blankesteijn \& Schouffoer, 2018).

After these challenging times, Han Golterman resigned as director of the Limnological Institute in 1978 and moved to Leiden University and then to Arles (France): the beginning of a new era for the Golterman family. In the Camargue, which Han and his wife Nel had already visited on their honeymoon, Han Golterman met Luc Hofmann and came to work at the Station Biologique Tour du Valat. There, via his association Leiden-Camargue, Golterman continued to unravel water sediment interactions and P- and $\mathrm{N}$-cycles.

Besides research and his work for editorial staffs of limnological magazines, he focused on education, which he provided in many places, such as Leiden and Delft universities, at the IHE-Unesco Institute and in many other places in the world! The Camargue was also a place where Han and Nel welcomed a lot of students, Ph.D. students, and other colleagues (his socalled équipe limnologique) from many different countries.

During his entire career, Han Golterman (Figs. 1, 2) had a great international network of bright colleagues, including Dicky Clymo (Westfield College), Curt Forsberg (Uppsala Universitet), and Laura Serrano (Universidad de Sevilla) who all became very close friends. His international work brought him two memberships of honour: from the Fresh Water Biological Association and the Asociación Iberica de Limnologia.

Every one of us chemists, biologists, geologists, has beautiful memories of the time we spent with Han in 
Fig. 1 Dr. Han Golterman (standing front right) amongst colleagues and host Dr. Livia Pirocchi Tonolli (left) at the first symposium of the International Biological

Programme (IBP), 1965 Istituto di Idrobiologia, Verbania Palanza, Italy

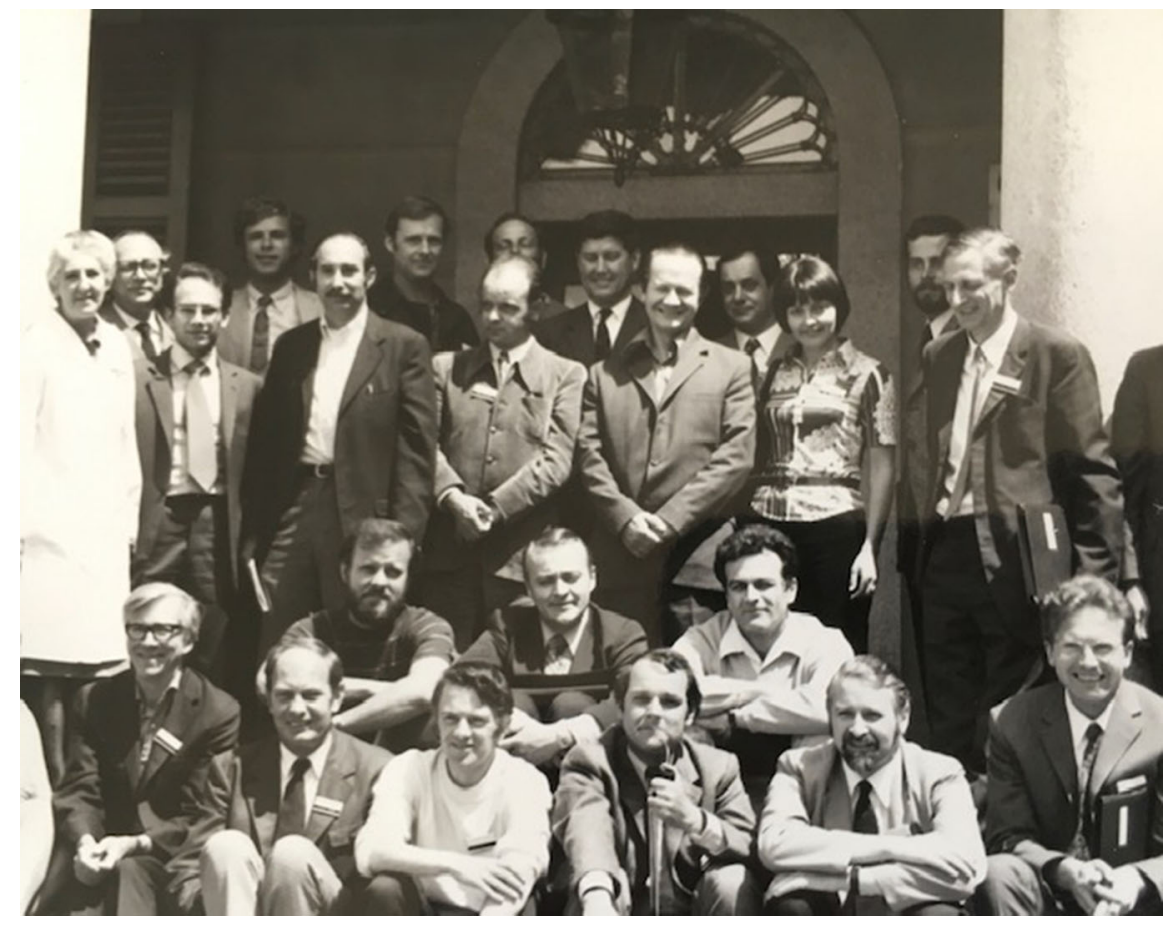

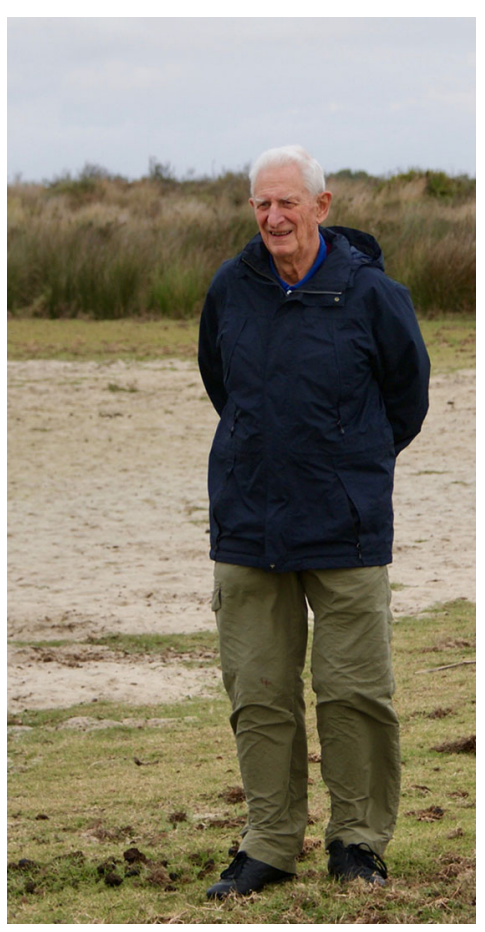

Fig. 2 Dr. Han Golterman visiting the Doñana ponds, Cota Doñana, Spain, November 2009 [picture Dr. Laura Serrano] the Camargue. Han and Nel were very hospitable and generous. Limnology led to long-lasting and sometimes very close friendships! Until the very end of his life, Han Golterman was truly interested in the people he worked with and cared for.

Working together with Han Golterman was in many aspects formative for the rest of our days. Han inspired confidence, not only when he saw you working but actually also at your start as a member of his equipe. Han Golterman stood for his convictions and was very firm in his scientific and all other convictions. Nevertheless, as a true man of science he was always willing to discuss and renounce... if you had the right arguments! For him results were leading and he could bring across that message firmly, but with humour, by quoting Hamlet for example 'Though this be madness, yet there is method in it...'

In the preface to his last published book on nutrient cycles, Han Golterman gives a clue about his 'raison d'être' as a scientist. When he started his career as limnologist, he was warned by the well-known Dutch microbiologist Kluyver that sediment studies were difficult. Kluyver therefore advised him not to study the sediment layer for the first 10 years. At the end of 
his career, Golterman states that "this is still true to some extent, although our equipment and methods have much improved and [..] nowadays we can leave behind us the outdated concepts like "sediment is a sink or source of phosphate". Han Golterman's studies show us that sediment is an integrated part of lakes and rivers and a large part of sediment phosphate remains bioavailable (Golterman, 2004). The true teacher Golterman warns us in his last publication also about legend forming as a serious problem in science. As former editor of sediment issues of Hydrobiologia, he all too often found that authors quote articles without having read these articles themselves. That increases the risk and makes it even more difficult for new concepts to become part of limnology. He referred again to Baas Becking and hopes that his work will help to improve the understanding of the chemistry and the interaction between field and laboratory studies. His widely known IBP Handbook "Methods for physical and chemical analysis of freshwaters" published in 1978 as well as the book on "The chemistry of phosphate and nitrogen compounds in sediment", published in 2004, are legacies to quantitative science. A comprehensive overview of publications authored or co-authored by Han Golterman can be found in a special issue of Hydrobiologia on Nutrient Cycles (Gulati, 1995) and annex to this obituary.

\section{An everlasting empirical legacy}

As a chemist working in the aquatic field, Han Golterman applied chemistry in limnology with a strict quantitative approach. He was well aware of the misfortunes of biologists tackling questions about environmental chemistry, and remarked "most biologists do not love chemistry: if they did, they would have been become chemists, but applying chemistry to the field of biology has always given me the greatest satisfaction". His numerical quantification of the capacity of the sediment to bind phosphate (or P-binding capacity) has brought on an empirical model of a chemical equilibrium of phosphate concentrations between the solid phases within the sediment and their adjacent soluble phases (water and porewater). Taken into account that the amount of total $\mathrm{P}$ is always much larger in the sediment than in the water, the P-binding capacity of the sediment will be the result of chemical adsorption, release, and precipitation processes that together govern the concentration of phosphate remaining in the water. Some chemical factors and, most importantly, the general biological activity of aquatic organisms also affect this equilibrium, namely uptake of $\mathrm{P}$ by primary producers, iron hydroxide in the sediment, $\mathrm{Ca}^{2+}$ in the water, and the changes of $\mathrm{pH}$ in the sediment during organic matter decomposition (as well as the influence of water $\mathrm{pH}$, temperature, and ionic strength on the physical adsorption of P). Golterman modelled this chemical equilibrium following the empirical power equation of a Freundlich adsorption isotherm, which described the phosphate concentration in the water as a function of the total concentration of $\mathrm{P}$ in the sediment, with sediment P-binding capacity as the parameter describing the slope. He empirically established that the exponent of this relationship was close to onethird, and explained that this proportion was in agreement with the theoretical assumption of two adsorption sites becoming inactivated by each phosphate molecule adsorbed onto the iron hydroxides occurring in the sediment at a $\mathrm{pH}$ range of 6-10 (Golterman, 1995a). He also produced a method to measure the sediment P-binding capacity through the sequential fractionation of $\mathrm{P}$ in the sediment, where the extraction by chelating agents of inorganic $\mathrm{P}$ compounds has to be carried out before the remaining organic $\mathrm{P}$ pool could be quantified to avoid major interferences (Golterman, 1996).

Several conclusions can be drawn from Han Golterman's chemical equilibrium model that are key in the interpretation of $\mathrm{P}$ cycling in aquatic systems. Firstly, his model grants us the view that sediment is not a permanent sink because it ensures some release of phosphate from the sediment to the water; the sediment acts as a savings account in relation to P: when there is more than needed, the sediment will adsorb it, and if the demand is larger it will release it. Secondly, the amount of $\mathrm{P}$ in the water is neither linearly related to the total concentration of $\mathrm{P}$ in the sediment, nor to the P external load, but follows an adsorption-saturation model. This implies that the sediment P-binding capacity becomes saturated under a constant $\mathrm{P}$ load, and sooner or later, a large concentration of phosphate will be built up in the water from the $\mathrm{P}$ released by the sediment, thus making the initial success of our eutrophication mitigation efforts short-lived once the sediment 
becomes saturated. Finally, a corollary is that shallow water bodies (e.g. rice fields, wetlands, ponds) proved to be a better paradigm than deep-stratified lakes when studying nutrient cycling. Both nutrients ( $\mathrm{N}$ and $\mathrm{P}$ ) can limit the primary production of wetlands (Golterman, 1995b), and although the $\mathrm{N}$ cycle in wetlands is dominated by complex denitrification biological processes, $\mathrm{P}$ is strongly adsorbed by sediments via chemical mechanisms that have been numerically quantified and empirically modelled thanks to Golterman.

Han Golterman contributed in several ways to great progress in limnology, and to a better world, as our common interest. Together with everyone who has been part of his 'equipe limnologique', we all will remember Han with much gratitude and respect.

\section{List of main publications authored or co-authored by Golterman}

Bonetto, C., F. Minzoni \& H. L. Golterman, 1988. The Nitrogen cycle in shallow water sediment systems of rice fields. Part II. Fractionation and bioavailability of organic nitrogen compounds. Hydrobiologia 159: 203- 210.

Clymo, R. S. \& H. L. Golterman, 1985. Precision and accuracy of the determination of the ionic product of hydroxy-apatite. Hydrobiologia 126: 31-34.

De Graaf Bierbrauwer-Würtz, I. M. \& H. L. Golterman, 1989. Fosfaatfracties in de bodem van een aantal Nederlandse meren. H2O 22: 411-414.

De Groot, C. J. \& H. L. Golterman, 1990. Sequential fractionation of sediment phosphate. Hydrobiologia, 192: 143-149.

De Groot, C. J. \& H. L. Golterman, 1993. On the presence of organic phosphate in some Camargue sediments: evidence for the importance of phytate. Hydrobiologia: 252: 117-126.

El Habr, H. \& H. L. Golterman, 1987. Input of nutrients and suspended matter into the Golfe du Lion and the Camargue by the river Rhône. Sciences de l'Eau 6: 393-402.

El Habr, H. \& H. L. Golterman, 1990. In vitro and in situ studies on nitrate disappearance in watersediment systems of the Camargue (southern France). Hydrobiologia 192: 223-232.
Ekholm, P., J. Lehtoranta \& H. Golterman, 2005. Reflections on the determination of the potential availability pf phospate to algae. In: Serrano, L. \& H. L. Golterman (Eds.), Phosphates in Sediments. Proceedings of the $4^{\text {th }}$ International Symposium Carmona, Spain, September 9-12, 2003. Backhuys Publishers, Leiden. 202 pp.

García-Gil, J. \& H. L. Golterman, 1993. Influence of $\mathrm{FeS}$ on the denitrification rate in sediments from Camargue (France). FEMS-Microbiology Ecology 13: 85-92.

Golterman, H. L., 1960. Studies on the cycle of elements in freshwater, Acta Botanica Neerlandica, Vol. 9, afl.1: 1-58.

Golterman, H. L., 1973a. Deposition of river silts in the Rhine and Meuse delta. Freshwater Biology 3: 267-281.

Golterman, H. L., 1973b. Natural phosphate sources in relation to phosphate budgets: a contribution to the understanding of eutrophication. Water Research 7: 3-17, International Water Association. Golterman, H. L., 1973c. Verical movement of phosphate in freshwater. In E.D. Griffith, A. Beeton (Ed.), Environmental Phosphorus Handbook. John Wiley, New York, N. Y., pp. 509-538

Golterman, H.L., 1975a. Chemistry. In: River ecology; ed. B.A. Whitton. Oxford etc., Blackwell, 1975; Studies in Ecology 2: p. 39-80.

Golterman, H. L., 1975b. Physiological Limnology. An approach to the Physiology of Lake Ecosystems. Elsevier, Amsterdam, Oxford, New York. 489 pp Golterman, H. L., 1976a. Zonation of mineralization in stratifying lakes. In: The role of terrestrial and aquatic organisms in decomposition processes; 17th Symposium of the British Ecological Society, 15-18 April 1975; eds. J.M. Anderson \& A. Macfadyen. Oxford etc., Blackwell, 1976; p. 3-22. Golterman, H. L., 1976b. The sediments and their importance, relative to the inflows, as a source of nutrients for the growth of algae. In: Proceedings of a Symposium "The effects of storage on water quality”, Reading University, March 1975, organized by the Water Research Centre, Medmenham Laboratory, Medmemham; p. 47-59.

Golterman, H. L., 1977a. Sediments as a source of phosphate for algal growth. In: H.L. Golterman (Ed.) Interactions between sediments and freshwater. Proceedings of an International Symposium 
held at Amsterdam, 6-10 September 1976 Junk/ Pudoc, The Hague, p. 286-293.

Golterman, H. L., (Ed.) 1977b. Interactions between sediments and freshwater. Proceedings of an International Symposium held at Amsterdam, 6-10 September 1976 Junk/Pudoc, The Hague. 473 pp.

Golterman, H. L., 1980. Phosphate models, a gap to bridge. Hydrobiologia 72: 61-71.

Golterman, H. L., 1982a. Loading concentration models in shallow lakes. Hydrobiologia 91: 169-174.

Golterman, H. L., 1982b. Differential extraction of sediment phosphates with NTA solutions. Hydrobiologia 92: 683-687.

Golterman, H. L., 1984. Sediments, modifying and equilibrating factors in the chemistry of freshwaters. Verhandlungen des Internationalen Verein Limnologie 22: 23-59.

Golterman, H. L., 1985. (Ed.) Denitrification in the $\mathrm{N}$-cycle. Nato Conference series; Series I: Ecology. Plenum Press, New York \& London, 294 pp.

Golterman, H. L., 1988. The calcium- and iron bound phosphate phase diagram. Hydrobiologia 159: 149-151.

Golterman, H. L., 1991a. Reflections on post O.E.C.D. eutrophication models. Hydrobiologia 218: 167-176.

Golterman, H. L., 1991b. The influence of FeS on the denitrification rate. Verhandlungen des Internationalen Verein Limnologie 23: 3025-3028.

Golterman, H. L., 1991c. Direct Nesslerization of ammonia and nitrate in freshwater. Annales de Limnologie 27: 99-101.

Golterman, H. L., 1994. Nouvelles connaisssances des formes du phosphate: conséquences sur le cycle du phosphate dans les sédiments des eaux peu profondes. Annales de Limnologie 30: 221-232.

Golterman, H. L., 1995a. Theoretical aspects of adsorption of ortho-phosphate onto Ironhydroxide. Hydrobiologia 315: 59-68.

Golterman, H. L., 1995b. The role of the ironhydroxide-phosphate-sulphide system in the phosphate exchange between sediments and overlying water. Hydrobiologia 297: 43-54.

Golterman, H. L., 1995c. The labyrinth of nutrient cycles and buffers in wetlands: results based on research in the Camargue (Southern France) Hydrobiologia 315: 39-58.
Golterman, H. L., 1995d. Remarks on numerical and analytical methods to calculate diffusion in water/ sediment systems. Hydrobiologia 315: 69-88.

Golterman, H. L., 1996a. Fractionation of sediment phosphate with chelating compounds: a simplification, and comparison with other methods. Hydrobiologia 335: 87-95.

Golterman, H. L., 1996b. A volumetric or colorimetric determination of $\mathrm{FeS}$ and $\mathrm{H} 2 \mathrm{~S}$ in sediments by oxidation to sulphate. Hydrobiologia 335: 83-86. Golterman, H. L., 1998. The distribution of phosphate over iron-bound and calcium-bound phosphate in stratified sediments. Hydrobiologia 364: $75-81$.

Golterman, H. L., 1999. Quantification of P-flux through shallow, agricultural and natural waters as found in wetlands of the Camargue (S-France). Hydrobiologia, 392: 29-39.

Golterman, H. L., 2000. Denitrification and a numerical modelling approach for shallow waters. Hydrobiologia 431: 93-104.

Golterman, H. L., 2001. Phosphate release from anoxic sediments or 'What did Mortimer really write'. Hydrobiologia 450: 99-106.

Golterman, H. L., 2004. The Chemistry of Phosphate and Nitrogen Compounds inSediment. Kluwer Academic Publishers, Dordrecht, pp. 251.

Golterman, H. L., 2005. Chemistry and limnology: A marriage de raison? In: Serrano, L. \& H. L. Golterman (Eds.), Phosphates in Sediments. Proceedings of the $4^{\text {th }}$ International Symposium Carmona, Spain, September 9-12, 2003. Backhuys Publishers, Leiden. 202 pp.

Golterman, H. L., 2006. Reviewing problems and possibilities for the analysis of phytate and polyphosphates. Archiv für Hydrobiologie 166: 525-534.

Golterman, H. L. \& F. A. Kouwe, 1980. Chemical budgets and nutrient pathways. Chapter 4, in: Functioning of freshwater ecosystems. Ed. by E. D. Le Cren \& R. H. Lowe-McConnell, IBP 22. Cambridge University Press, London. 588 pp.

Golterman, H. L. \& M. L. Meyer, 1985. The geochemistry of two hard water rivers, the Rhine and the Rhone. Hydrobiologia 126. 3-10 (Part 1); Hydrobiologia 126: 11-19 (Part 2); Hydrobiologia 126: 21-24 (Part 3); Hydrobiologia 126: 25-29 (Part 4). 
Golterman, H. L \& A. Booman, 1988. Sequential extraction of iron-phosphate and calcium-phosphate from sediments by chelating agents. Verhandlungen des Internationalen Verein Limnologie 23: 904-909.

Golterman, H. L \& N. T. De Oude, 1991. Eutrophication of Lakes, Rivers and Coastal Seas. In: Hutzinger, O. (Ed.), The Handbook of Environmental Chemistry, volume 5A, page 79-124. Springer Verlag, Berlin, Heidelberg.

Golterman, H. L. \& I. M. De Graaf-Bierbrauwer, 1992. Colorimetric determination of sulphate in freshwater with a chromate reagent. Hydrobiologia 228: 111-115.

Golterman, H. L. \& C. J. De Groot, 1994. Nouvelles connaissances des formes du phosphate: conséquences sur le cycle du phosphate dans les sédiments des eaux douces peu profondes. Annales de Limnologie 30: 221-232.

Golterman, H. L., C. C. Bakels \& J. JakobsMögelin, 1969. Availability of mud phosphates for the growth of algae. Verhandlungen des Internationalen Verein Limnologie 17: 467-479.

Golterman, H. L., A. B. Viner, \& G. F. Lee, 1977. Preface in Golterman, H. L. (Ed.), Interactions between Sediments and Freshwater. pp. 1-9. Junk, The Hague.

Golterman, H. L., R. S. Clymo \& M.A.M. Ohnstad, 1978. Methods for physical and chemical analysis of fresh waters, IBP Handbook 8, 3rd edition. Blackwell Scientific Publications, Oxford; 214 pp.

Golterman, H. L, P. Sly \& R. L. Thomas, 1983. Study of the relationship between water quality and sediment transport. UNESCO, Technical Papers in Hydrology, 26. Unesco, Paris. 232 pp.

Golterman, H. L., F. Minzoni \& C. Bonetto, 1988. The Nitrogen cycle in shallow water sediment systems of rice fields. Part III. The influence of $\mathrm{N}$-application on the yield of rice. Hydrobiologia 159: 211-217.

Golterman, H. L., P. Bruijn, J. G. M. Schouffoer \& E. Dumoulin, 1998. Urea fertilization and the $\mathrm{N}$-cycle of rice-fields in the Camargue (S. France). Hydrobiologia 384: 7-20.

Golterman H.L., J. Paing, L. Serrano \& E. Gomez, 1998. Presence of and phosphate release from polyphosphates or phytate phosphate in lake sediments. Hydrobiologia 364: 99-104.
Miltenburg, J. C. \& H. L. Golterman, 1998. The energy of the adsorption of o-phosphate onto ferric hydroxide. Hydrobiologia 364: 93-97.

Minzoni, F., C. Bonetto \& H. L. Golterman, 1988. The Nitrogen cycle in shallow water sediment systems of rice fields. Part I: The denitrification process. Hydrobiologia 159: 189-202.

Moutin, T., P. Raimbault, H. L. Golterman \& B. Coste, 1998. The input of nutrients by the Rhone river into the Mediterranean Sea: recent observations and comparison with earlier data. Hydrobiologia 373/374: 237-246.

Povoledo, D. \& H. L. Golterman, 1975. Humic substances; Their structure and function in the biosphere. Proceedings of an international meeting held at Nieuwersluis, the Netherlands, May 29-31, 1972. Centre for Agricultural Publishing and Documentation, Wageningen. 368 pp.

Reina, M., L. Serrano \& H. L. Golterman, 2011. A sequential procedure for the quantification of biologically produced polyphosphate in sediment samples. Limnetica 30: 17-26.

Serrano, L., M. Reina, E. de Verdi, J. Toja \& H. L. Golterman, 2000. Determination of the sediment phosphate composition by the EDTA method of fractionation. Limnetica 19: 199-204.

\section{References}

Baas Becking, L. G. M., 1934. Geobiologie, Den Haag, Van Stockum \& Zoon.

Blankesteijn, M. L., 2011. Tussen wetten en weten: de rol van kennis in waterbeheer in transitie. Boom Lemma, Den Haag.

Blankesteijn, M. L. \& Schouffoer, J.G.M., 2018., Wanneer wordt waterkwaliteit een probleem? Water Governance tijdschrift 03/2018, STOWA

Golterman, H. L., 1977a. Sediments as a source of phosphate for algal growth. In: H.L. Golterman (Ed.) Interactions between sediments and freshwater. Proceedings of an International Symposium held at Amsterdam, 6-10 September 1976 Junk/Pudoc, The Hague, p. 286-293.

Golterman, H. L., (Ed.) 1977b. Interactions between sediments and freshwater. Proceedings of an International Symposium held at Amsterdam, 6-10 September 1976 Junk/Pudoc, The Hague. 473 pp

Golterman, H. L., 1995a. Theoretical aspects of adsorption of ortho-phosphate onto Ironhydroxide. Hydrobiologia 315 : 59-68. 
Golterman, H. L., 1995b. The labyrinth of nutrient cycles and buffers in wetlands: results based on research in the Camargue (Southern France). Hydrobiologia 315: 39-58.

Golterman, H. L., 1996. Fractionation of sediment phosphate with chelating compounds: a simplification, and comparison with other methods. Hydrobiologia 335: 87-95.

Golterman, H. L., 2004. The Chemistry of Phosphate and Nitrogen Compounds in Sediments. Kluwer Academic Publishers, Dordrecht: 251.
Gulati, R., 1995. Dr Han L. Golterman, a limnologist: a tribute on the occasion of his 65 th birthday and retirement. Hydrobiologia 315: 1-6.

Publisher's Note Springer Nature remains neutral with regard to jurisdictional claims in published maps and institutional affiliations. 